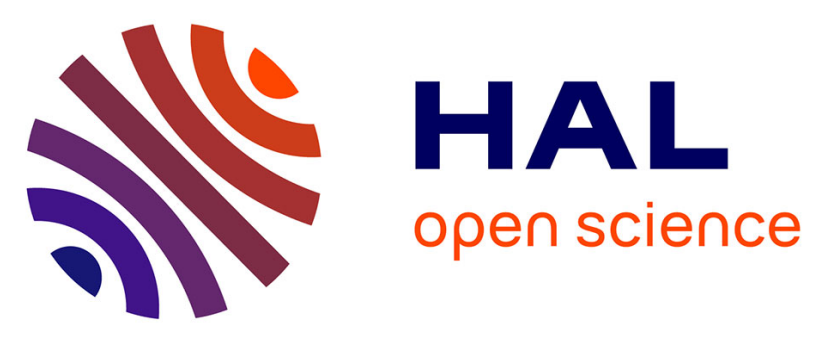

\title{
Sporulation and physiological profiles of bacterial communities of three Mediterranean soils affected by drying-rewetting or freezing-thawing cycles
}

Laurent Daou, Mathieu Luglia, Claude Perissol, Virgile Calvert, Steven Criquet

\section{To cite this version:}

Laurent Daou, Mathieu Luglia, Claude Perissol, Virgile Calvert, Steven Criquet. Sporulation and physiological profiles of bacterial communities of three Mediterranean soils affected by dryingrewetting or freezing-thawing cycles. Soil Biology and Biochemistry, 2017, 113, pp.116-121. 10.1016/j.soilbio.2017.06.008 . hal-01681641

\section{HAL Id: hal-01681641 https://hal.science/hal-01681641}

Submitted on 3 May 2018

HAL is a multi-disciplinary open access archive for the deposit and dissemination of scientific research documents, whether they are published or not. The documents may come from teaching and research institutions in France or abroad, or from public or private research centers.
L'archive ouverte pluridisciplinaire HAL, est destinée au dépôt et à la diffusion de documents scientifiques de niveau recherche, publiés ou non, émanant des établissements d'enseignement et de recherche français ou étrangers, des laboratoires publics ou privés. 
Sporulation and physiological profiles of bacterial communities of three Mediterranean soils affected by drying-rewetting or freezingthawing cycles

Laurent Daou ${ }^{1}$, Mathieu Luglia, Claude Périssol, Virgile Calvert, Stéven Criquet $^{*}$ Aix Marseitte Univ, Univ Avignon, CNRS, IRD, IMBE, Marseitte, France

\begin{tabular}{|c|c|}
\hline & A B S T R A C T \\
\hline $\begin{array}{l}\text { Keywords: } \\
\text { Freezing-thawing } \\
\text { Drying-rewetting } \\
\text { Community level physiological profiles } \\
\text { Soil respiration } \\
\text { Mediterranean soil vulnerability } \\
\text { Climate change }\end{array}$ & $\begin{array}{l}\text { In the global change context, the basal respiration (BR), the estimated number of bacterial spores (SP) } \\
\text { and the community level physiological profiles (CLPPS) were investigated in three different Mediterra- } \\
\text { nean soils following different hydric and thermic stress scenarios. The treatments consisted in an } \\
\text { increasing number }(1,2,4, \text { and } 7 \text { ) of drying-rewetting (DRWC) or freezing-thawing cycles (FTC) at } 20,40 \\
\text { or }-200^{\circ} \text {. The results highlighted that the different soils responded differently to the same treatment } \\
\text { and that the three variables considered were weakly related one to each another. In almost all soils and } \\
\text { modalities, the BR increased significantly during the first cycles before decreasing during the last. With } \\
\text { regards to SP, it appeared that, for a given soil, the capacity of microbial communities to sporulate and/or } \\
\text { germinate can be considerably more influenced by the temperature rather than by the hydric stress. } \\
\text { Finally, the CLPPs literally collapsed with the treatment at } 40{ }^{\circ} \mathrm{C} \text {, irrespective of the soil considered. This } \\
\text { suggested a progressive replacement of the catabolically diversified original bacterial communities by } \\
\text { another showing lower functional diversities. }\end{array}$ \\
\hline
\end{tabular}

\section{Introductio}

Soil microbial communities are known to be sensitive to climate (Chemidlin Prevost-Boure et al., 2011), and it is globally admitted that under Mediterranean climate, the global change will lead to heat and drought waves that will durably affect the terestrial ecosystens (IRC, 2014), in part through increased vulnerability of coils subjed to clinstic stresses are begin docums sules

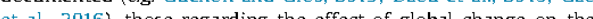
cal a cataber. sporut tent despite the importance of sporulating microorganisms in soil

* Corresponding author. E-mait addresses. laurent.daou@îusherbrooke.ca (L. Daou), mathieu.luglia@imbe (V. Maglia), clade.perissol@imb fr.

ratoire d'Écologie Fonctionnelle, Sherbrooke,e, Québec J1K 2R1, Canada. functioning. Indeed, among the affected microorganisms, the spore-forming bacteria are known to be particularly abundant in soils and it was demonstrated that their abundance and their specific richness could be influenced by hydric and thermic characteristics of their environment (Périssol et al., 1993; Brunel et al, 1954). Thus, the objectives of this study were to determine how different thernal $\left(-20^{\circ} \mathrm{C},+20^{\circ} \mathrm{C}\right.$ or $\left.+40^{\circ} \mathrm{C}\right)$ and/or hydric stress scenarios, i.e. diyng tion (BR) the estimated number of bacterial spo (SP) and the comment (BR) of soil mity level phsiog factor (DRWC/FTC or temperature) most influences the different microbial variables and if the responses observed are me the oriain and the and the responses observed are modulated by the different Mediterranean soils investigated.

\section{Materials and methods}

Mesocosm experiments were conducted (Fig. 1) with three each) collected during February 2014 in the Bouches-du-Rhône, 


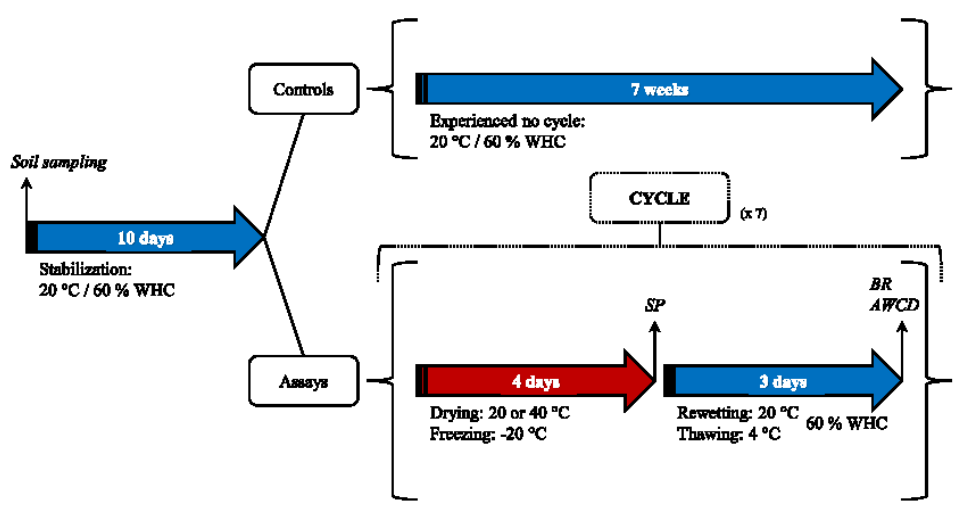

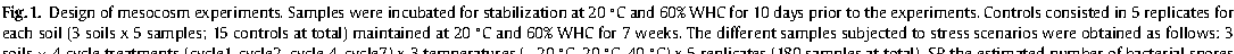

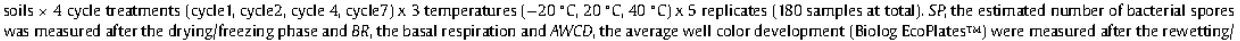
thawing phase. WHC, water holding capacity. 195 mesocosms at total.

France. A south oriented soil (S) $\left(43^{\circ} 19^{\prime} 5^{\prime \prime} \mathrm{N}, 5^{\circ} 40^{\prime} 2^{\prime \prime}\right.$ E, $900 \mathrm{~m}$ altitude), a north oriented soil ( $\mathrm{N}$ ), opposite to the south oriented plot ( $43^{\circ} 19^{\prime} 29^{\prime \prime} \mathrm{N}, 5^{\circ} 40^{\prime} 23^{\prime \prime} \mathrm{E}, 700 \mathrm{~m}$ altitude), and a riparian forest soil (R) $\left(43^{\circ} 31^{\prime} 11^{\prime \prime} \mathrm{N}, 5^{\circ} 34^{\prime} 10^{\prime \prime}\right.$ E, $420 \mathrm{~m}$ altitude). For each soil, samples were sieved at $2 \mathrm{~mm}$, pooled into one composite sample, and the dry mass (DM) and the water holding capacity (WHC) were determined prior to the experiments. The textures of soils were classified as clay loam ( $\mathrm{S}$ and $\mathrm{N}$ soils, Colluvic Rendzic Leptosols; JUSS, 2006) and silty clay loam (R soll, Calcaric Stagnic Fluvisol; USS, 2006). The three solls showed an alkaline $\mathrm{pH}^{-1}$.6), and similar caton exchange capacity (22.8-24.8 ch) nitrogen content (4.4-5.0 $\mathrm{g} \mathrm{kg}^{-1}$ DM). The total organic carbon and $\mathrm{N}$ sols $\mathrm{Cons} .4,64.7$ and $82.4 \mathrm{~g} \mathrm{~kg}-1 \mathrm{DM}$,

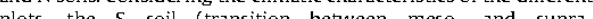
Mediterranean bioclimatic stages) was, along the year, subjected to more drastic temperature and relative humidity varions the the $\mathrm{R}$ soil (medio-european influences). The pedoclimatic conditions of the $\mathrm{N}$ soil (supra-Mediterranean-subhumid bioclinatic stage) appeared as intermediary to the two other soils. See Appendix A for more details about floristic inventories of plots and physicochemical and pedoclimatic characteristics of soils (Dand et al., 2016). The BR was measured according to the technique of Anderson and Domsch (1978), using gas chromique of (Chrompack CHROM 3 - CP 9001, equipped with a Porapak ${ }^{T M}$ column type, under a helium flux of $650 \mathrm{~mL} \mathrm{~h}^{-1}$ ). The Biolog EcoPlates ${ }^{T M}$ technique was used according to the protocol of Floch et al. (2011) to determine the metabolic potentialities (i.e. CLPPs) of aerobic heterochemoorganotroph communities of soils. After $72 \mathrm{~h}$ of growth in microplate, the average well color development (AWCD, i.e. average metabolic activity) was calculated according to the method of Garland and Mills (1991) and was used as indicator of the CLPPs (Preston-Mafham et al., 2002). Relative use of several classes of substrates (polymers, carbohydrates, carboxylic acids, amino acids, amines and miscellaneous) was also calculated according to Selmants et al. (2005). To achieve this, each class of substrate was calculated as corrected absorption values, i.e. divided by total absorption in the plate. The number of bacterial spores was estimated by using the most probable number method (MPN) and the algorithm developed by Briones and Reichardt (1999). Briefly, $1 \mathrm{~g}$ of soil was suspended in $9 \mathrm{~mL}$ of $0.1 \%$ sterile sodium pyrophosphate solution, then agitated for $20 \mathrm{~min}$ at $50 \mathrm{rpm}$ (ie. $5 / 6 \mathrm{~Hz}$ ) and submitted to decimal dilutions with a $0.85 \%$ sterile $\mathrm{NaCl}$ solution. The different dilutions were thereafter pasteurized at $80^{\circ} \mathrm{C}$ for 10 min to eliminate non sporulated microorganisms and to preserve the bacterial spores (Travers et al., 1987). $20 \mu \mathrm{L}$ of these dilutions were inoculated in 96 wells microplates ( $\mathrm{NunC}^{\mathrm{TM}}$ ) filled with $180 \mu \mathrm{L}$ of agnostics) ind calculation of the MPN.

Concerning statistics, prior to analyses, the hypotheses of data normality (Shapiro-Wilk test) and variance homogeneity (Bartlett sures alyses of vari eace (rANOVA) tere performed crobial variable to test the effect of cycle factor (within-subject factor: four levels: $1,2,4$ and 7 cycles), at a significance level of $p<0.05(n=5)$. Thereafter, a post hoc test of pairwise multiple comparisons of Tukey (honestly significant difference HSD) was used to verify whether the various levels of the tested factor were significantly different from each other, at a significance level of $p<0.05$. For each soil, analyses of variance (ANOVA) were performed on each microbial variable of the last cycles to test the effect of temperature factor (between-subject factor; three levels: -20 , 20 , and $\left.40^{\circ} \mathrm{C}\right)$, at a significance level of $p<0.05(n=5)$. Thereafter, a post hoc test of comparisons with a control of Dunnett was used to verify whether the various levels of the tested factor were significantly lower (left-tailed test) or greater (right-tailed test) than the control, at a significance level of $p<0.05$. All these analyses were conducted using XLSTAT software version 2009.3.02 (Addinsoft ${ }^{\mathrm{TM}}$, France).

\section{Results and discussion}

For all soils, results showed that the temperature, the cycles and their interaction had significant effects on BR (Table 1). Moreover, 
Table 1

Fivalues or he repeated measures ANOVA for the temperature (Temp), cycle (Cycle, both DRWC and

\begin{tabular}{llllllll}
\hline Soil & Factor & BR & & SP & & AWCD & \\
\hline $\mathrm{S}$ & Temp & 367.5 & $* * *$ & 11.2 & $* *$ & 32.1 & $* * *$ \\
& Cycle & 271.2 & $* * *$ & 1.6 & & 12.4 & $* * *$ \\
& Temm $x$ Cycle & 34.2 & $* * *$ & 3.2 & $* *$ & 0.8 & $* *$ \\
$\mathrm{~N}$ & Temp & 263.3 & $* * *$ & 14.0 & $* *$ & 68.0 & $* * *$ \\
& Cycle & 110.3 & $* * *$ & 1.0 & & 38.0 & $* *$ \\
& Temp $x$ Cycle & 18.1 & $* * *$ & 2.1 & & 5.3 & $* *$ \\
$\mathrm{R}$ & Temp & 74.9 & $* * *$ & 28.9 & $* *$ & 113.7 & $* *$ \\
& Cycle & 61.0 & $* * *$ & 9.8 & $* *$ & 29.5 & $* * *$ \\
& Temp $x$ Cycle & 14.2 & $* *$ & 22.1 & $* *$ & 5.9 & $* *$ \\
\hline
\end{tabular}

$S$, soil from south slope; $N$, soil from north slope; $R$, soil from riparian forest; $B R$, basal respiration; SP, estimated number of bacterial spores; $A W C D$, average well levels, $1,2,4$, and 7 cycles; Temp is the between-subject factor with three
levels, $-20,20$, and $400^{\circ} C_{*}^{*}, \cdots, \cdots$, significant at $p<0.05,0.01,0.001$.

BR increased significantly between the 1 st and the 4 th cycle, except for the $R$ soil at $-20^{\circ} \mathrm{C}$ ( Fig. 2). However, between the 4 th and the
7 th cycle, a systematic and significant decrease of $B R$ was observed for all soils and temperatures. The increases observed during first for alles are consistent with cycles are consistent with numerous other studies (Kuzyakov et al., Gros, 2013). Indeed, the DRWC are known to induce a brutal raise of BR called the 'priming effect'. Even though it is mentioned to be rapidly dmopping down, in some studies it has been detected for up to 7 days after rewetting (Fierer and Schimel, 2003: Wang et al. 2003). The reasons of this effect are still discussed but two explanations are often outlined. On one hand, the DRWc can induce, by an osmotic shock, an immediate loss of microbial biomass due to the cell lysis, as proven by Guénon and Gros (2013) in Mediterranean soils. The surviving microorganisms would thereafter mineralize the organic carbon released from dead microbial biomass, resulting in an increased soil BR as observed by Fierer and Schimel (2003) after the rewetting of two Mediterranean soils. On the other hand, the second most often outlined explanation is that the observed pulse is due to the mineralization of osmoregulation related compounds, which are accumulated in cells to resist to osmotic/hydric stress. During rewetting, cells which can rapidly getting rid of these compounds indease the amount of easily degradable $\mathrm{C}$ sources in the soil and ipso facto the soil BR. Indeed, Warren (2014) showed that osmolyte quantities, which were 10 times higher in stressed soils compared to unstressed controls, rapidly dropped down to the control levels after rewetting. Finally, the brutal drop of respiration values observed in all mesocosms between the 4 th and the 7hi cycle could be relevant of a resistance threshold to DRWc beyond which the microbial biomass is significantly impacted whatever the soll and the incubation temperature.
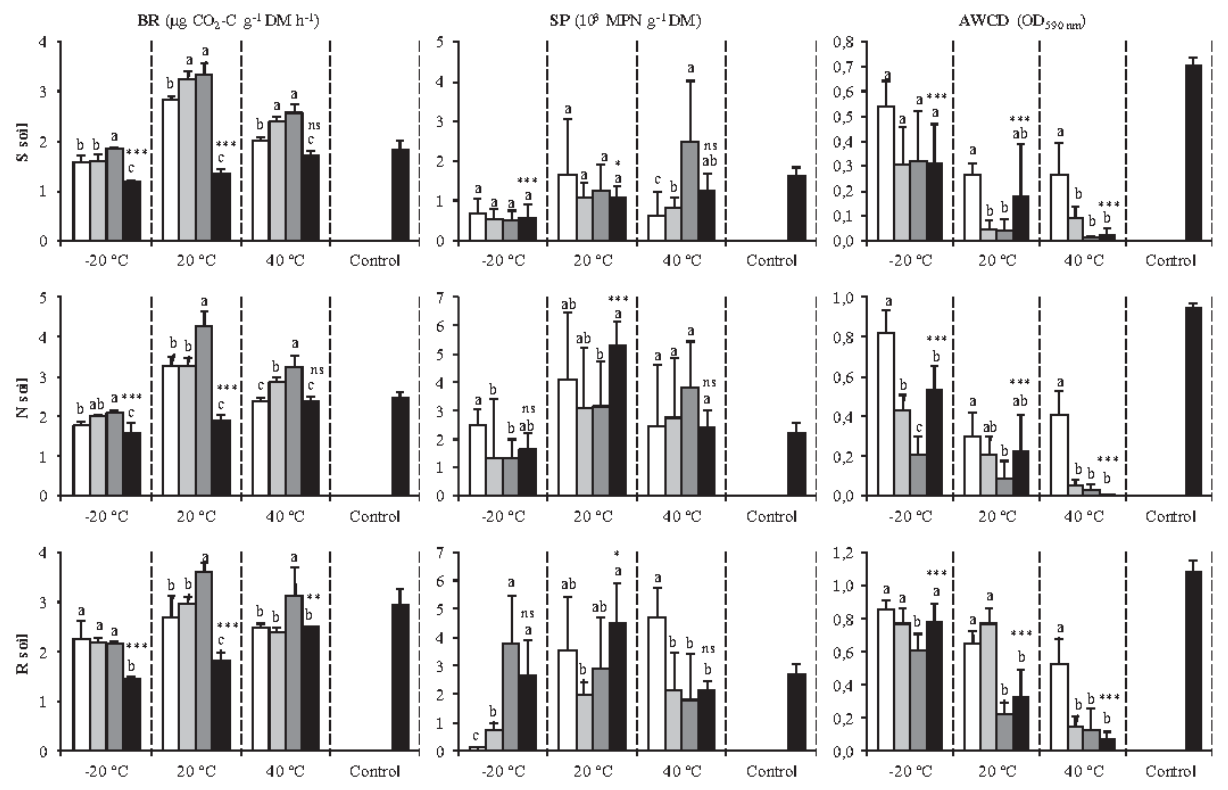

Fig. 2 Basal respiration (BR), estimated number of bacterial spores (SP), and average well color development (AWCD; Biolog Ecoplatestad) of the three soils. Bars depict means $(n=5)$ with standard deviations (in brackes). The soils experienced 7 drying-rewetting cycles (DRWC) at 20 or $40^{\circ} \mathrm{C}$, or 7 freezing-thawing cycles (FTC) at $-20^{\circ} \mathrm{C}$. Controls were temperature modality followed by the same tetters do not differ significantly from each other at $p<0.05$. For each graph, btack bars (last cycle) followed by stars are significantly lower or greater than the control at $p<0.05$. " 
a result that corroborates previous studies which argued that such climatic events are comparable to DRW events since they also limit water availability to micrabia cells and thus can result in simitar effects on soll microbial respiration (Schimel et al, 2007). With regards to the bacterial spores, the cycles did not significantly influence their number in the $\mathrm{S}$ and $\mathrm{N}$ soils, only the temperature did. It was only in the R soil that sporulation was significantly impacted by the double stress and its interaction (Table 1). In this soil, two modalities were of particular interest, i.e. -20 and $40^{\circ} \mathrm{C}$, since the observed responses were reversed. Actually, at $-20^{\circ} \mathrm{C}$ an explosion of the number of spores along with an increasing number of FTC was noticed, Whereas the DRWC at $40^{\circ} \mathrm{C}$ induced the opposite phenomenon (Fig. 2), probably because lysis of vegetative cells of spore-forming bacteria (SFB) occurred at high temperature. At $20{ }^{\circ} \mathrm{C}$ the number of spores of this soil was not significantly impacted by temperature, DRWc or their interaction. One is limited to speculations when it comes to explain these results. It appeared that the first Fe destroyed most of the spores initially present in $R$ soil. During the following incubation at $4{ }^{\circ} \mathrm{C}$, and since spores formed at low temperature are known to be more cold tolerant than spores formed at higher temperatures (Nicholson et al., 2000; Carin et al., 2010), the increase in the number of spores during the next FTc of the soil $R$ may be explained by the fact that the newly formed spores would be more tolerant to our treatment. Additionally, spores formed from the most psychrotrophic groups of SFB possess better germination abilities at low temperature $\left(\right.$ i.e. $7^{\circ} \mathrm{C}$ ) trophic groups possessing by definito better survival rates to our trophe groups possessing, by defition, beter sum. prising if their abudance insessed duing the expering prising if their abor sponses of the two other soils at $-20{ }^{\circ} \mathrm{C}$ could be due to a higher abundance of cold a dapted connunities. Indeed according to Von Stetten et al (1999) the abundance of psychrotrophic strains is steter et al. (limate the ab in tropical soil and high in mountain soill. Since the $S$ and $N$ soils are submitted to colder temperatures, it soil). Since the $S$ andising if they also exhibit a higher abundares, it more psychrotrophic strains.

Considering the CLPPs, both the DRWC (or FTc) and the temperature had significant effects on the bacterial functional diversity (Table 1) and, when significant, they induced diversity losses (Fig. 2). However, correlations between the ClPPs and the other variables, as well as between the whole set of variables, were globally weak and ranged between -0.54 and 0.29 (data not shown). This is not very surprising since these three variables do not concern the same microbial communities. Indeed, the BR concerns whole fungi and bacteria, the CLPs only consider extractable bacteria capable of growing in Biolog EcoPlates ${ }^{\mathrm{TM}}$; while the SP only concerns the SFB. At $-20^{\circ} \mathrm{C}$, even if the CLPPs at the end of the experiment were generally lower than the controls, no or only weak significant effects of the consecutive Frc were observed in the three different soils. Yergeau and Kowalchuk (2008) also obtained very low functional responses to frequent $F T$ in soils regularly submitted to freezing events, even if their study was conducted on a different pedosysten (i.e. Antarctic soil).

However, as mentioned by these authors, and since the soils investigated during our study also freeze regularly during winter (37-46 times during 2014-15 winter), an explanation for the low responses in observed CLPPs would be that part of the soil micoThe community may be adapted to freezing-thawing events.

The experiments performed at $40{ }^{\circ} \mathrm{Cp}$ rovided results especially marking in ters of we the 7th cycle, with decreses of 870 in Rsil, $90 \%$ in s soll and up to

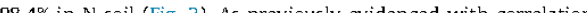

calculations, these impressive collapses in microbial functional diversities were not related to variations in the number of spores nor in $\mathrm{BR}$, which are known to reflect the physiological state and the nent of soil microbial biomass (Blagodatskaya and Kuzyakov, 2013). Indeed, according to Anderson and Joergensen (1997), the BR is strongly correlated with total microbial biomass (ie. bacteria and fungi). Thereby, explanations to this massive decrease in CLPs under hot drastic climatic stress, cannot be supported exclusively on the basis of quantitative evolution of the microbial biomass. It is more likely though that, as mentioned by Guénon and Gros (2013), changes occurred in the composition of microbial communities and in their associated catabolic properties. Thus, it can be hypothesized that following intense stresses, occurred a progressive replacement of the original community, functionally diversified, by another less functionally diversified. However, a methodological bias of the Biolog technic cannot also be discarded. Indeed, this method only allows for extractable microbial fraction. In soils, there might be a large part of the microbial community that is not extractable, but still plays a major ecological role. The CLPPs were done on the extractable part of the community, and it may be difficult to make a general conclusion based on this method on microbial functional diversity. To assert this point of view, it would be interesting in further studies to explore, using molecular methods, if the collapse of functional diversity can be At a finer scale the rel dive use at the end of thmunities.

At a finer scale, the relative use at the end of the experiment (cycle 7 of the difeested substrates as cabon sources was also uses varied during the experiment, especially at $+40^{\circ} \mathrm{C}$ (Fig. At $-20^{\circ} \mathrm{C}$, the freezing thawing treatment did not indue any significant difference betheen the treathent 7 and the cond the carboxylic acid in $S$ soil and the carbohydrates and amino acids in $\mathrm{R}$ soil. The same applied to a lesser extend at $+20^{\circ} \mathrm{C}$. Indeed, in the $\mathrm{N}$ soil, no significant effect was detected except for the carbohydrates. In $S$ and $R$ soils, the carbohydrate relative use varied between the cycle 7 and the control. Also, at this temperature the tween the cycle 7 and the control. Also, at this temperature the
relative use of amines varied. Finally, the most interesting results relative use of amines varied. Finally, the most interesting results
were observed at $+40^{\circ} \mathrm{C}$. At this temperature in the different soils, carbohydrate, amino acid and amine relative uses varied significantly in terms of decreases or increases. Finally, as also observed with the raw AWCD values, results of these relative uses seem also to indicate a possible shift in microbial functional populations.

\section{Conclusions}

Results obtained during our different stress scenarios corroborated in most cases our hypothesis which was that hydric and thermic stress influence significantly the microbial variables considered. When significant, the effects observed on these variables, were mainly negative, and the temperature effect was always stronger than the hydric cycle effect (DRWc and FTc) as well as the interaction effect of both (Table 1). Another result was that the different variables were weakly related when considering their evolution in the different mesocosms. Indeed, with regards to the basal respiration ( $B R$ ), this variable showed during the first cycles a well-known "priming effect", followed by a decrease of this activity during the last cycles; a dynamic pattern that was observed in all mesocosms (soils and temperature) and that was not correlated with any other variable. Considering the bacterial spores (SP), it appeared that their number was considerably more infuenced by hydric stress hility stess perfor literally collapsing duing the conseutive DRWe. in fiture 
Polymers Carbohydrates carboxylic acids Amino acids
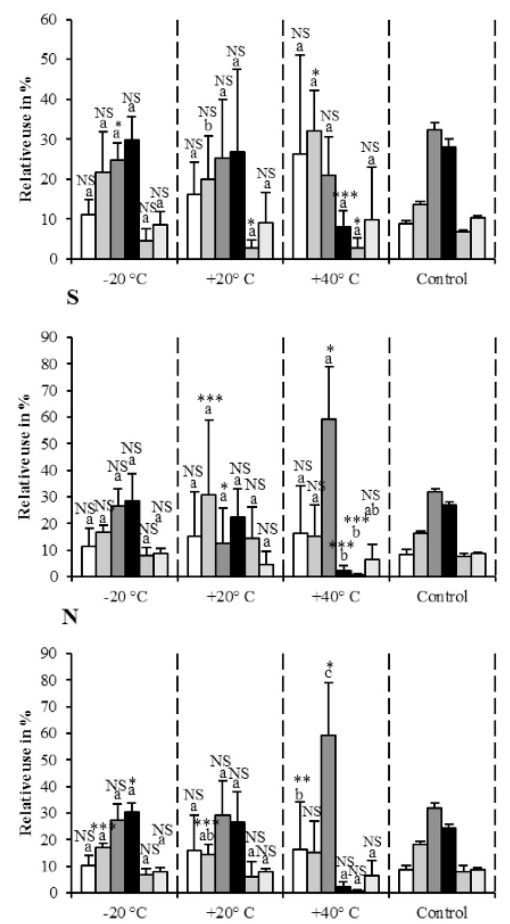

Fig. 3. Relative use (\%), of the different substrates as carbon sources by extractable bacteria grown for $72 \mathrm{~h}$ in Biolog EcoPlates 5 d4. Bars depict means $(n=5)$ with standard deviations (in brackets). The soils experienced 7 drying-rewetting cycles (DRWc) at 20
or $400^{\circ} \mathrm{C}$, or 7 freezing-thawing cycles (FTC) at $-20^{\circ} \mathrm{C}$. Controls were maintained at or $4{ }^{\circ}{ }^{\circ} \mathrm{C}$, or 7 freezing-thawing cycles (FTC) at $-20{ }^{\circ} \mathrm{C}$. Controls were maintained at
$20^{\circ} \mathrm{C}, 60 \%$ WHC, and experienced no cycle. White bars, polymers; tight gray bars, $20{ }^{\circ}, 60 \%$ WHC, and experienced no cycle. White bars, polymers; , gight gray bors,
carbohydrates; dark gray bors, carboxylic acids, btack bars, amino acids, very tight gray, amines, very pate groy, miscell laneous. For each groph, bars within a same temperature modality followed by different tetters differ significantly from each other at $p<0.05$. Missing letters indicate non-significant differences. For each sol, the last cycle was compared to control and stars indicate significantly lower or greater values than the
control at $p<0.05 * * * *$ s. significant at $p<0.05,0.01,0.001 .: N 5$, non-significants soil from south slope; $N$, soil from north slope; $R_{\text {, soil from riparian forest }}$

relationships between these variables and more especially the influence of environmental factors on the capacity of microbial populations to sporulate and/or germinate. Indeed, this constitutes a microbial life trait still poorly explored in soll science despite its

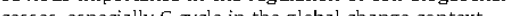

\section{Acknowledgements}

We warmly thank Mrs. Sophie Gachet (IMBE) for her assistance in the vegetation diagnosis, and Mrs. Catherine Keller (CEREGE) for her help in the determination of soil types. We also would like to acknowledge Mr. Michael Paul for improving the English of the manuscript.
This research did not receive any specific grant from funding agencies in the public, commercial, or not-for-profit sectors.

\section{Appendix A. Supplementary data}

Supplementary data related to this article can be found at http:/ dx.doi.org/10.1016/j.soilbio.2017.06.008.

\section{References}

Anderson, J.P.E., Domsch, K.H., 1978. A physiological method for the quantitative measurement of microbial biomass in soils. Soil Biology \& Biochemistry 10 , Anderson, T.-H., Joergensen, R.G., 1997. Relationship between SIR and FE estimates of microbial biomass $\mathrm{C}$ in deciduous forest soils at different pH. Soil Biology and Biochemistry 29, 1033-1042.
Blagodatkkaya, E, Kuzyakov, Y, 2013. Active microorganisms in soil: critical review of estimation criticria and approaches. Soil Biology \& Biochemistry $67,192-211$
ond

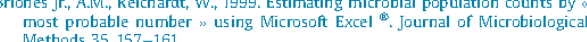

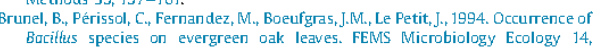
$331-342$. mp, S., Shaheen, R., Salonen, M.S.

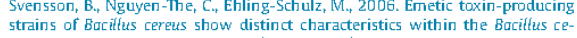
reus group. International Journal of Food Microbiology 109, 132-138.
Carlin, $F_{\text {, }}$ Brillard, J, Broussole,, ., Clavel, T., Duport, C., Jobin, M., Guinebretierre, M.H., Auger, S., Sorokine, A, Nguyen-Thé, C., 2010. Adaptation of Baciftus cereus, an
ubiquitous worldwide-distributed foodborne pathogen, to a changing envi-

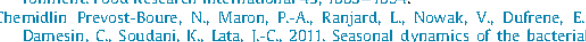
and
ommunity in forest soils under different quantities of leaf litter. Applied Soil Daou, L, Périssol, C., Luglia, M., Calvert, V., Criquet, S., 2016. Effects of drying-

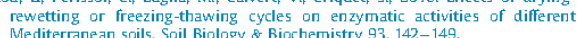
Mediterranean soils. Soil Biology \& Biochemistry 93, $142-149$.
Fierer, N., Schimel I.J.P., 2003. A proposed mehannism for the pulse in carton dioxide

Floch, C., Chevremont, A.-C., Joanico, K., Capowiez, Y pesticite contantiation. soll enzyme compared to functional diversity of 47, 256-263. Gao, J.Q, Feng, J.,ZZhang, X.W., Yu, F..., Xu, X.L, Kuzyakov, Y, 2016. Drying-rewetting
cycles alter carton and nitrogen mineralization in litter-amended alpine wetland soil Catena $145,285-200$.

Garland, .L., Mills, A.L., 1951. Classification and characterization of heterotrophic microbial communities on the basis of pattems of community-level sole-car-
bon-source utilization. Applied and Environmental Microbiology 57, eñon, R., Gros, R., 2013. Frequent-wildfires with shortened time-since-fire affect soil microbial functional stability to drying and reweting events. Sor Biology \& IPCC, 2014. Climate change 2014: impacts, adaptation and vulnerability. In:
Field, C.B., Barros, V.R., Dokken, D.J, Mach, K.J., Mastrandrea, M.D., Bili, T.E.,
Chatterjee, M., Ebi, K.L., Estrada, Y.O., Genova, R.C., Girma, B., Kissel, E.S., Chatterjee, M., Ebi, K.L, Estrada, Y.O., Genova, R.C., Girma, B., Kissel, E.S.,
Levy, A.N., MacCracken, S., Mastrandrea, P.R., White, LL (Eds.), Contribution of Working Group II to the Fifth Assessment Report of the Intergovernmental Panel on Climate Change. Cambridge University Press, Cambridge, UK, p. 1132.
IUSS Working Group WRB, 2006. World Reference Base for Soil Resources 2006 (World Soil Resources Report 103), second ed. FAO, Rome.
(a)

Kuzyakrov, Y,., Frieddel, J.K., Stahr, K., 2000. Review of mechanisms and quantification of priming effects. Soil Biology \& Biochemistry 32, 1485-1498.

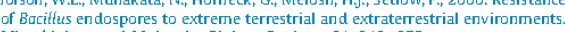

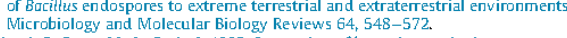
Perissol, C., Roux, M., Le Petit, J., 1993. Succession of bacteria attached to evergreen oak leaf surfaces. European Joum al of Soil Biology 29, $167-176$.
Preston-Mantham, J., Boddy, L, Randerson, P.F, 2002. Analysis of microbial community functional diversity using sole-carbon-source utilization profiles - a critique. FEMS Microbiology Ecology 42, 1-14.

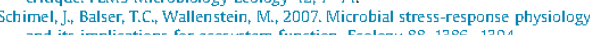
Selmants, P.C., Hart, S.C., Boyle, S.I., Stark, J.M., 2005. Red alder (Alnus rubra) alters community-level soil microbial function in conifer forests of the Pacific 
Travers, R.S., Martin, P.A.W, Reichelderfer, C.F, 1987. Selective process for efficient
isolation of soil Baciftus spp. Applied and Environmental Microbiology 53, isolation of soil Baciftus spp. Applied and Environmental Microbiology 53,
$1263-1266$. Unger, S., Máguas, C., Pereira, JS., David, TS., Werner, C., 2010. The influence of

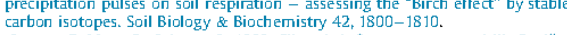
Von Stetten, $F_{\text {, Mayr, }}$,. Scherer, S., 1999. Climatic influence on mesophilic Bacilltus cereus and psychrotolerant Bacifitus weihenstephanensis population in tropical,
temperate and alpine soil. Environmental Microbiology $1,503-515$. Wang, WJ., Dalal, R.C., Moody, P.W, Snith, C.J., 2000. Relationships of soil respi-
ration to microbiail biomass, substrate availability and clay content. Soil Biology
\& Biochemistry $35,273-284$. \& Biochemistry $35,273-284$.
Warren, C.R., 2014. Response of osmolytes in soil to drying and rewetting. Soil Warren, C.R., 2014. Response of osmolytes in soil to drying and rewetting. Soil
Biology \& Biochemistry 70,22 -32.
Yergeau, E. Kowalchuk, GA, 2008. Responses of Antarctic soil microbial communities and associated functions to temperature and freeze-thaw cycle frequency.
Envirimonmental Microbiology $10,2223-2235$. 